\title{
Evaluation of the use of the Moodle Platform for Fundamental Physics Lectures at University
}

\author{
Mutoharoh $^{1, \mathrm{a})}$, Diah Ambarwulan ${ }^{2, \mathrm{~b})}$ \\ ${ }^{1)}$ Industry Engineering Study Program, Universitas Krisnadwipayana, Bekasi, Jatiwaringin, 13077, \\ Indonesia \\ ${ }^{2)}$ Physics Education Study Program, Faculty of Mathematics and Natural Sciences, \\ Universitas Negeri Jakarta, Jakarta, 13220, Indonesia

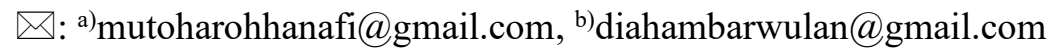

\begin{abstract}
Almost all countries in the world use E-Learning as a teaching medium. Moodle is a Learning Management System (LMS), a free, open-source platform designed to assist educators in creating online courses with dynamic interaction opportunities. In this study, an evaluation of the use of Moodle was carried out, especially in fundamental physics courses (Newton's Law). Evaluation is given by distributing online questionnaires using Google Forms as a database to store answers, collect feedback, and as statistical software to provide analysis of the effect of using Moodle according to students' opinions or perspectives. The study results show that students experience problems in taking tests/quizzes using SEB due to the instability of the internet signal. One of the reasons is that students also have to join the exam zoom simultaneously. Meanwhile, the Newton's Law material provided is very contextual and rich in sample questions, including providing student feedback which is considered good.
\end{abstract}

Keywords: e-learning, evaluation, moodle, fundamental physics

\section{INTRODUCTION}

Nowadays, there is a transformation from traditional learning to online learning. In this era, educators of all classes and contexts are experiencing the need to rethink their roles, ways of supporting student learning tasks (Rodríguez-Triana et al. 2020; Nordmann et al. 2020), and students' image as self-regulating learners, active citizens, and agents of social autonomy. This shift requires new learning for teachers and students (Rapanta et al. 2021). Due to the emergence of the internet, social media, globalization, and the World Wide Web, these things cause a lot of data that requires special techniques to deal with it, thus causing the need to use E-Learning.

Researchers studied the benefits of E-Learning, where learners do not need teachers to be in the exact physical location, which will complement and support traditional face-to-face learning (Rasool $\&$ Dawood 2021). Clark and Mayer (2011) define the term E-Learning as: "instruction delivered on a digital device such as a computer or mobile device intended to support learning". Anderson (2008) believes that E-Learning, distance learning, Internet learning, virtual learning, and other online terminology describe learning being practiced online. The authors argue that regardless of which term is used, they have things in common such as: all of them use some form of technology (usually a computer) to access learning materials and the learners and tutors are at different distances from each other and use technology to interact with each other. 
Learning Management System (LMS) is a software application for administration, documentation, reports preparation, organizing training and education courses, or learning and development programs. The LMS concept is ejected directly from e-Learning. For this reason, LMS is the core of any ELearning system, be it commercial or open-source LMS platforms (Shahzad et al. 2014). There are many reasons to add and integrate LMS with university education. Such as respecting their infrastructure, increasing flexibility, accessibility, scalability, solving the problem of limited physical space by using virtual content, reducing course fees, increasing their ranking to cooperate with global developments and technology, as well as being able to compete with other universities in the world (Nagy 2016; Deepak 2017). LMS encourages students to work closely with instructors to quickly access courses and cooperate with virtual education networks because young people are now more interested in social media and the internet, as seen in the referenced paper (Rasool 2018). Students are also affected by social media because there is an association relationship between social media and education on campus, so that LMS will increase student knowledge.

Moodle (compliant with Modular Object-Oriented Dynamic Learning Environment) is a free and open-source E-Learning platform designed to provide educators, administrators, and learners with one robust, secure and integrated system for creating personalized learning environments. Moodle provides users with several flexible tools that can be used primarily remotely to access course materials, including lecture slides, assignments, quizzes, and news (Deepak 2017). Most of these course materials are prepared using Microsoft Office software, which teachers can upload to the E-Learning system. Moodle also provides several interactive learning tools. The teacher can set up the tools using the functionality of the Moodle module, including feedback, discussion forums, workshops, chats, wikis, questionnaires, and surveys, as well as managing their assignments with their schedules. In addition to offering a wide range of complementary tools to support the teaching and learning process (Ivanović 2013).

Many papers and research studies the Moodle platform, studies on Moodle functionality and its tools in the University. The study was conducted by analyzing the results of interviews with their students and showed that Moodle depended on its use in teaching materials (Halim et al. 2020). Another survey about Moodle evaluation is given by giving 46 feedback to students. The results show that Moodle's interactive tools are not used actively (Bahsh \& Daoud 2016). Only access materials are used. It imposes an expansion of the use of these tools for interactive learning environments. Other studies and researchers using the Moodle platform in college should force universities to change how they teach E-Learning strategies (Rasool \& Dawood 2021). The evaluation was obtained from the results of interviews to collect their data. Moreover, evaluation is needed in order to develop a better E-Learning.

Evaluation of the use of Moodle in fundamental physics courses was carried out through online questionnaire feedback from a sample of students. Google Form is created as a DataBase (DB) to store the answers obtained from this questionnaire to perform statistical analysis of the survey results. Many people also chose Google forms because they can be used to create surveys to collect answers online by sending a link message, email or embedding it into a blog post on their page. There are many online survey apps on the internet, but Google Forms is an excellent free choice between students and teachers to share questions and answers or create surveys (Kato et al. 2016). Google Forms supports various questions such as text, which is used for short text answer questions. The paragraph type is for longer text (or essay) answer questions. Multiple choice is for questions where the respondent can only choose one item as the answer. Choose from lists, checkboxes, scales, and grids, allowing respondents to select more than one item.

Therefore, this article will discuss the evaluation of the use of the Moodle Platform for Fundamental Physics Lectures at University-Level Students, especially on Newton's law material. Evaluation is done by distributing online forms using Google Forms

\section{METHODS}

The data collection method is used by distributing online questionnaires using Google Form. The questionnaire is a data collection technique done by giving a set of written questions to respondents to answer. The questions given include an assessment of the physics material being taught, skills in using Moodle, and obstacles in using Moodle. Queries are distributed to students who have taken or are 
currently taking fundamental physics courses (Industry Engineering Study Program), with the teaching media used being Moodle. The answer to questions about the physics material is given in the form of a 1-5 Likert scale (Abazid \& Gökçekuş 2019), where:

$1=$ strongly disagree

$2=$ disagree

$3=$ neutral

$4=$ agree

$5=$ strongly agree

While questions about skills in using Moodle and the questions about obstacles in using Moodle were answered using yes or no answers.

\section{RESULTS AND DISCUSSION}

E-learning fundamental physics on Newton's Law material is shown in Figure 1. In Figure 1, the material is given a brief explanation of each topic to understand it easily. For example, initial information is given in the quiz section regarding the number of questions, technical work (open book, close book), using Save Exam Browser (SEB) or not.

SEB (Schneider et al. 2012) is free, open-source software available for Windows and Mac OS. SEB helps deter fraud in online exams by preventing access to unwanted resources and utilities such as system functions, websites, applications and files, and turning any computer into a safe exam tool. SEB consists of two main components: (1) kiosk applications that prevent access to unwanted resources and utilities (Miller, Vandome \& McBrewster 2010); and (2) a browser to create a test environment. Stall components lock the computer by preventing access to unwanted utilities by blocking commands (e.g., keyboard shortcuts and pop-ups) or making them inaccessible by removing them from the user interface (e.g., task manager, start menu, or third parties software). The browser component creates the exam environment by accessing the exam learning management system modules via the Internet or LAN (Halbherr et al. 2014). Therefore, at the same time, students must also join the exam zoom to use two devices during the exam. one to access the exam one to participate in zoom.

In addition, when collecting quizzes, students are asked to fill in identities such as name, study program, and student number for convenience in the assessment process later. Suppose the student's name is clearly written on the worksheet. The lecturer does not need to flip through the browser window to find out who the assignment owner is.

The material given is very contextual. It can be seen from how the lecturer relates the concept of physics to the surrounding environment in everyday life. In addition, many examples of questions are given in the attached material. The provision of many examples of questions is expected to facilitate students in solving physics problems (FIGURE 2). Students are given practice questions or quizzes as feedback from the learning process. The questions presented are included in the High Order Thinking Skills (HOTS) level so that students can think more critically and creatively. To make it easier for students, lecturers also provide pictures related to examples of questions and assignments. 


\section{HUKUM NEWTON \\ Dashboard / My courses / HUKUM NEWTON}

\section{高 PENDAHULUAN}

Materi ini berisi hukum newton I,II, III dengan tambahan materi dengan gesekan dan tanpa gesekan Referensi

1. Tipler

2. Halliday Resnick

3. Seway

4. Giancoli

5. Prof. Mikrajudin

6. Semua yang berhubungan dengan Hukum Newton 1,11 , II

(a)

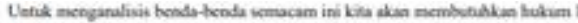

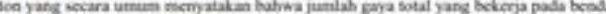

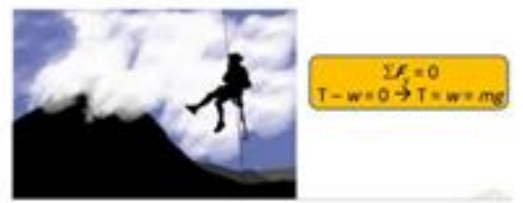

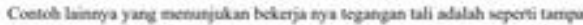

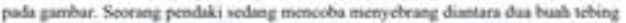

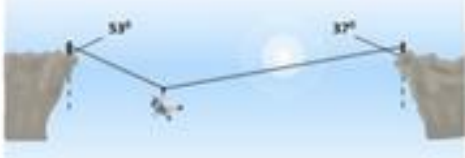

(c)

\section{HUKUM 1 NEWTON}

'G. MATERI HUKUM 1 NEWTON

SILAKAN DOWNLOAD FILE INI SEBAGAI SALAH SATU REFERENSI BELAJAR KALIAN

$\checkmark$ KUIS HUKUM 1 NEWTON

1. KUIS BERSIFAT OPEN SOURCE

2. KERJAKAN DENGAN MENGGUNAKAN CARA

3. TERDIRI DARI 5 SOAL ESAI

4. TULISKAN JAWABAN HANYA DALAM BENTUK ANGKA.

5. DESIMAL MENGGUNAKANTITIK

BUKTI PEgERJAAN KUIS HUKUM 1 NEWTON

1. SILAKAN UPLOAD CARA KaLLAN DALAM FORMAT DOKUMEN (PDF ATAU. DOC ATAU DOCX) MAX 5 MB 2. PADA BAGIAN POIOK KANAN ATAS PENGERIAAN BERULAH IDENTITAS DIRI SEPERTI: NAMA, PRODI NIM.

(b)
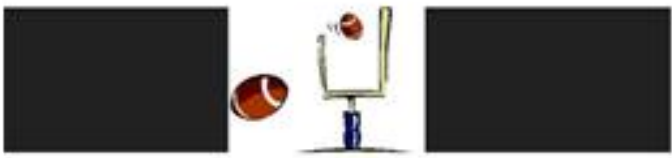

Gravitan

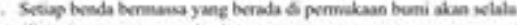
dikenti percopatan grovitos:

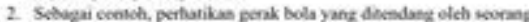
pemain ke tengath lapangan.

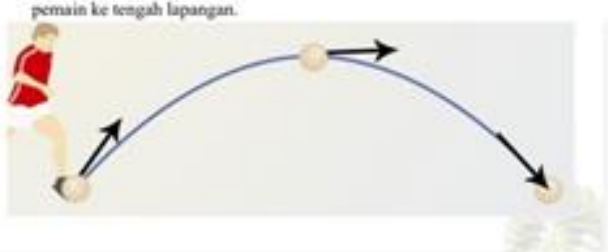

(d)

FIGURE 1. (a) Shows the fundamental section in each chapter (b) One of the teaching materials in Newton's 1st law includes attachments to teaching material documents, a quiz consisting of 5 questions, and uploading how to work, (c) examples of rope tension forces, (d) the effect of gravity and examples.

TABLE 1. Questionnaire result of the physics material

1. Learning to use e-learning makes me able to learn physics anywhere and anytime

2. Learning to use e-learning makes it easy for me to understand physics concepts

3. The material in the e-learning helps me understand the concept of physics

4. The material provided in e-learning is quite clear and easy to understand

\section{AVERAGE}

\begin{tabular}{cc} 
SCORE & CATEGORY \\
\hline 4.2 & Agree \\
4.1 & Agree \\
4.2 & Agree \\
4.2 & Agree \\
$\mathbf{4 . 2}$ & Agree
\end{tabular}




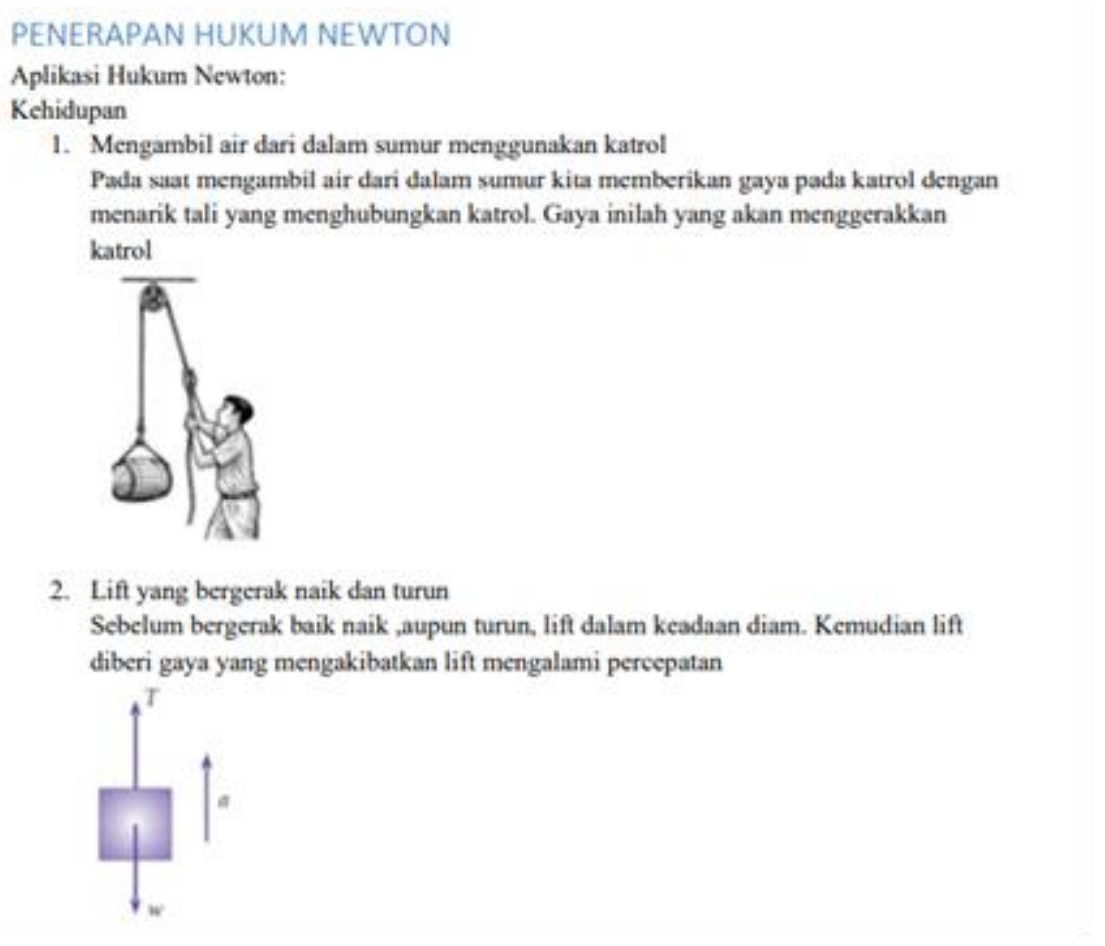

FIGURE 2. One of the materials that display pictures to clarify concepts to students

The evaluation questions in the form of a questionnaire are 17 questions and are presented in TABLE 1, TABLE 2 and TABLE 3. The total number of students who filled out the fundamental physics course questionnaire was 53 . While this study surveyed 53 students, only 45 forms from the questionnaire was accepted because eight forms ignored due to inaccuracy in data entry.

The data presented in Table 1 shows that Students agree that the lecturer gives the physics material to help students understand physics concepts. Even with e-learning, students can learn anywhere and anytime. Students find it easy to understand physics concepts because all teaching materials are available on the same website. Students do not need to search for themselves to avoid misconceptions. In this evaluation, it is necessary to pay attention to the minimum score of questions. the score of question number 2, learning to use e-learning, makes it easy for me to understand physics concepts gets the smallest which is 4.1 . Hence, it needs to be followed up. Given that e-learning strategies may not fully emulate live teaching. They serve as complementary additions to applicable education (Bradford et al. 2021). So, the ability of lecturers to represent a concept and limit multiple representations will not be able to provide a holistic and appropriate learning experience (Masrifah et al. 2020). This is because students have different abilities in constructing their knowledge.

TABLE 2. Questionnaire result of the skills in using moodle

\begin{tabular}{|c|c|c|}
\hline QUESTIONS & NO OF YES & PERCENTAGE \\
\hline 1. Have you used a Learning Management System before? & 38 & 84.4 \\
\hline 2. Have you ever used Moodle? & 38 & 84.4 \\
\hline 3. Do you think the Moodle platform is helpful for the learning process? & 37 & 82.2 \\
\hline 4. Do you feel confident using Moodle? & 38 & 84.4 \\
\hline 5. Do your lecturer use Moodle to create quizzes? & 36 & 80,0 \\
\hline $\begin{array}{l}\text { 6. Do you use Moodle to Communicate with your friends - using the } \\
\text { Moodle messaging system? }\end{array}$ & 26 & 57.8 \\
\hline $\begin{array}{l}\text { 7. Is the Moodle Platform an engaging way for your lecturer to teach } \\
\text { you? }\end{array}$ & 28 & 62.2 \\
\hline 8. Do you find the Moodle interface user-friendly? & 38 & 84.4 \\
\hline $\begin{array}{l}\text { 9. Do you find using Moodle with your lecturer teaching system a } \\
\text { valuable way to influence your education? }\end{array}$ & 37 & 82.2 \\
\hline $\begin{array}{l}\text { 10. I need to undergo more training to understand the Moodle Platform } \\
\text { better. }\end{array}$ & 39 & 86.7 \\
\hline AVERAGE & 36 & 78.9 \\
\hline
\end{tabular}


For the skill of using Moodle, there are ten questions. Out of 45 students, 38 students responded yes to every question. Interestingly the most questions with yes answers are question number 14, 'I need to undergo more training to understand the Moodle Platform better'. This is caused by students taking fundamental physics courses who are new students. New students came from various high schools and have not necessarily used Moodle. Therefore, students tend to want to learn more about Moodle. As for question number 9, 'Do your lecturer use Moodle to create quizzes?'. 36 students answered yes regarding Do your lecturer uses Moodle to create quizzes. This needs to be followed up, considering that every material being taught will be given a quiz on Moodle.

How students communicate using Moodle can be seen from question number 10. the value obtained is $57.8 \%$, meaning that only 26 students have ever communicated on Moodle. This is not surprising considering that many messaging applications are now more accessible and familiar for students. The next one that got the lowest score was question number 11, 'Is the Moodle Platform an engaging way for your lecturer to teach you?'. 28 students answering yes or 62.2\%. Low scores on question 11 because the Moodle interactive learning tool has not been used effectively. Moodle's interactive learning tools, including chats, wikis, feedback, forums, questionnaires, and surveys, are underutilized. The study results show that Moodle is mostly used as a place to get course material, but its interactive learning tools are not invested effectively. Therefore, those surveyed found that using Moodle with their teaching system was not a valuable method of influencing student education. In the future, this will be the task of academic staff. Academic staff needs to convince them of the usefulness of this system by introducing them to the experiences of other universities that have successfully developed their online education systems.

TABLE 3. Questionnaire result of the obstacles in using moodle

\begin{tabular}{|c|c|c|}
\hline QUESTIONS & NO OF YES & PERCENTAGE \\
\hline 11. Are there any problems in using Moodle? & 43 & 95.6 \\
12. Have you ever used SEB during an exam? & 49 & 86.7 \\
13. Are there any problems when using SEB with test zoom? & 42 & 93.3 \\
\hline AVERAGE & 41 & 91.9 \\
\hline
\end{tabular}

Finally, there were three questions regarding the difficulties in using Moodle, the majority of students answered yes. An average of 41 out of 45 students answered yes. This is because students are required to take the exam using SEB during the id or final exam and be present on camera at zoom. Problems exist around the internet, so some students provide backup internet sources when taking the mid or final exam.

\section{CONCLUSION}

This paper conducted a questionnaire-based study to evaluate using an e-learning system based on the Moodle platform from learning fundamental physics courses. Google Forms web-based application invested in creating a Database used to store collected answers and take advantage of the application's statistical analysis capabilities. The replies from the Surveyed indicated that most of them found The Moodle platform is helpful for the learning/teaching process. However, Moodle's interactive learning tools do not utilize effectively. Most surveys show a positive perspective of the use of E-Learning tools in the educational process through the expression of their desire to take training to get to know Moodle This LMS provides platforms and activities.

The results of our research recommend the Coordinator of the Industrial Engineering Study Program to improve internet services and operations to encourage the use of Moodle interactive learning tools in the education process to achieve a practical and interactive learning environment. Our future work will focus on surveying student views on this platform's effectiveness in improving the education system and the possibility of switching to E-Learning. 


\section{REFERENCES}

Abazid, M \& Gökçekuş, H 2019, 'Application of Total Quality Management in Saudi Arabia Construction Project', Journal of Advanced Research in Dynamical and Control Systems, vol. 11, pp. 38-43.

Anderson, T 2008, 'The Theory and Practice of Online Learning, 2nd ed. Athabasca', Canada: Athabasca University Press.

Bahsh, RE \& Daoud, MI 2016, 'Evaluating the use of moodle to achieve effective and interactive learning: A case study at the German Jordanian University', Proc. the 2nd International Conference on Open Source Software Computing (OSSCOM 2016).

Bradford, DN, Wilechansky, RM, Pipilas, AR 2021, 'Revamping Residency Education during a Pandemic with Twitter-Based Learning', Med.Sci.Educ. vol. 31, pp. 303-304.

Clark, RC \& Mayer, RE 2011, 'E-Learning and the Science of Instruction: Proven Guidelines for Consumers and Designers of Multimedia Learning', 3rd ed. Santa Ana, CA, USA: Pfeiffer.

Deepak, KC 2017, 'Evaluation of moodle features at Kajaani University of Applied Sciences - case study', Procedia Computer Science, vol. 116, pp. 121-128.

Halbherr, T, Reuter, K, Schneider, D, Schlienger, C \& Piendl, T 2014, 'Making Examinations More Valid, Meaningful And Motivating: The Online Exams Service At Eth Zurich', June 2014.

Halim, A, Soewarno, S, Elmi, E, Zainuddin, Z, Huda, I \& Irwandi, I 2020, 'The Impact of the ELearning Module on Remediation of Misconceptions in Modern Physics Courses', Jurnal Penelitian \& Pengembangan Pendidikan Fisika, vol. 6, no.2, pp. 203-216.

Ivanović, M, Putnik, Z, Komlenov, Z, Welzer, T, Hölbl, M \& Schweighofer, T 2013, 'Usability and privacy aspects of moodle: Students' and teachers' perspective', Informatica, vol. 37, no. 3, pp. $221-230$

Kato, T, Kambayashi, Y \& Kodama, Y 2016, 'Practice for self-regulatory learning using google forms: Report and perspectives', nformation Engineering Express International Institute of Applied Informatics, vol. 2, no. 4, pp. 11-20.

Masrifah, M, Setiawan, A, Sinaga, P \& Setiawan, W 2020, 'An Investigation of Physics Teachers' Multiple Representation Ability on Newton's Law Concept', Jurnal Penelitian \& Pengembangan Pendidikan Fisika, vol. 6, no. 1, pp. 105-112.

Miller, FP, Vandome, AF \& McBrewster, J (Hrsg.) 2010, 'Kiosk Software', Saarbrücken: VDM.

Nagy, T 2016, 'Using learning management systems in business and economics studies in Hungarian higher education', Education and Information Technologies, vol. 21, no. 4, pp. 897-917.

Nordmann, E, Horlin, C, Hutchison, J, Murray, JA, Robson, L, Seery, MK, \& MacKay, JR 2020, 'Ten simple rules for supporting a temporary online pivot in higher education', PLoS Computational Biology, vol. 16, no. 10.

Rapanta, C, Botturi, L, Goodyear, P, Guàrdia, L, \& Koole, M 2021, 'Balancing Technology, Pedagogy and the New Normal: Post-pandemic Challenges for Higher Education', Postdigit Sci Educ, vol. 3, pp. 715-742.

Rasool, JA \& Dawood, SS 2021, 'Evaluate the Use of Moodle Platforms for Education inUniversity of Duhok Using Online Survey Application', International Journal of Machine Learning and Computing, vol. 11, no. 2.

Rasool, JA 2018, 'Analysis the relationship between social media and education system in Kurdistan region of Iraq using Chi-Square test,' Academic Journal of Nawroz University, vol. 7, no. 4, pp. 133-138. 
Rodríguez-Triana, MJ, Prieto, LP, Ley, T, de Jong, T \& Gillet, D 2020, 'Social practices in teacher knowledge creation and innovation adoption: A large-scale study in an online instructional design community for inquiry learning', International Journal of Computer-Supported Collaborative Learning, vol. 15, no. 4, pp. 445-467.

Schneider, DR, Bauer, D, Volk, B, Lehre, M, Piendl, T 2012, 'The Safe Exam Browser: Innovative Open Source Software for Online Examinations', 18th International Conference on Technology Supported Learning \& Training.

Shahzad, A, Hafizi, W, \& Golamdin, AG 2014, 'E-learning navigation model based on students learning behavior: Case study in UUM', Int. J. Bus. Soc. Sci., vol. 5, no. 5, pp. 118-130. 